\title{
Building an optomechatronics group in a young university in Western Romania
}

Virgil-Florin Duma, Gheorghe Hutiu, Octavian Cira, Dorin Demian, Corina Mnerie, et al.

Virgil-Florin Duma, Gheorghe Hutiu, Octavian Cira, Dorin Demian, Corina Mnerie, losif Kaposta, "Building an optomechatronics group in a young university in Western Romania," Proc. SPIE 9289, 12th Education and Training in Optics and Photonics Conference, 928913 (17 July 2014); doi: $10.1117 / 12.2070774$

SPIE Event: 12th Education and Training in Optics and Photonics Conference, 2013, Porto, Portugal 


\title{
Building an Optomechatronics Group in a young university in Western Romania
}

\author{
Virgil-Florin Duma*, Gheorghe Hutiu, Octavian Cira, Dorin Demian, Corina Mnerie, Iosif Kaposta \\ 3OM Optomechatronics Group, Aurel Vlaicu University of Arad, 77 Revolutiei Ave., 310130 Arad, \\ Romania
}

\begin{abstract}
We present our experience regarding the establishing of an interdisciplinary group with Optics as one of its main topic at the Aurel Vlaicu University of Arad (UAVA) - linked with the improvement through research of our educational activities. The 3OM Group (in Opto-Mechatronics, Optical Metrology, and Optics \& Mechanics) is described in its evolution from optomechanics to photonics, the latter with a focus on OCT (Optical Coherence Tomography) - with the national and the international collaborations established, with universities from Romania, Europe and USA. While the research directions of the 3OM Group are presented, they are linked with the educational components implemented in the various subjects we teach, for both undergraduate and graduate students, both in Mechanical and in Electrical Engineering. The main effort is to integrate education and research, to move teaching beyond the classical aspects to put the stress on hands-on-experiments, as well as on research-based activities - even with undergraduates. The main goals of this approach are to obtain an early orientation towards innovation and discovery, with a taste for novelties and with a clear focus on international standards. While this account is only one of many, it offers our experience in passing through the difficulties of developing both research and education in Optics in a young university in an emergent economy in Eastern Europe.
\end{abstract}

Keywords: Optomechatronics, optomechanics, optical devices, optical systems, optical coherence tomography, optical metrology, education and training, collaborative research.

\section{INTRODUCTION}

Multi- and inter-disciplinarity are often the key to success in the complex landscape of nowadays science \& technology. The early introduction of mechatronics [1] by the Japanese has been a good demonstration of this principle. It integrated mechanics, electronics and IT in a system that has proven indeed more than the sum of its components. The next step towards this integration was done by adding optics to this equation and thus optomechatronics [2] was born. While the limit between the various combinations of these domains is not always clearly set, and some topics (devices, systems and methods) do cross the lines and they can be found (and are claimed) in optics, optomechanics, optoelectronics, by example - or under the larger umbrella of Photonics - optomechatronics is maybe the most comprehensive way of defining some R\&D directions that include topics such as those pointed out in Fig. 1.

This is why, when establishing a new multidisciplinary group with optics as one of its main components at a young Higher Education institution, the "Aurel Vlaicu" University of Arad - UAVA (founded in 1991 on the bases of an Engineering College founded in 1972), the name of 3OM Optomechatronics Group was chosen [3]. The "3OM" term stands for Optomechatronics, Optical Metrology, and Optics \& Mechanics to account for the multiple directions of research of the group when it was founded, in 2008, by Prof. Duma, PI of an IDEAS Grant of the Romanian National Authority for Scientific Research (CNDI-UEFISCDI) [4].

This paper will present the steps of establishing this group in a young university which had no previous tradition in Optics or in related fields, in a economy in transition - with the inherent low funding for R\&D activities despite the 2007 integration of the country in the European Union (EU). To these conditions an addition was made by the negative impact that the economic crisis in Europe had on the R\&D system during the last years. We will also present briefly the related

\footnotetext{
*dumavirgil@osamember.org; phone 40-751-511451; sites www.3omgroup.appspot.com/; http://3om-groupoptomechatronics.ro/
} 
training activities in research and educational implementations in the lectures and labs of the faculties involved - as a direct consequence of the experience gained and of the avenues opened by the R\&D activities of the Group.

\section{RESEARCH ACTIVITY: DIRECTIONS AND RESULTS}

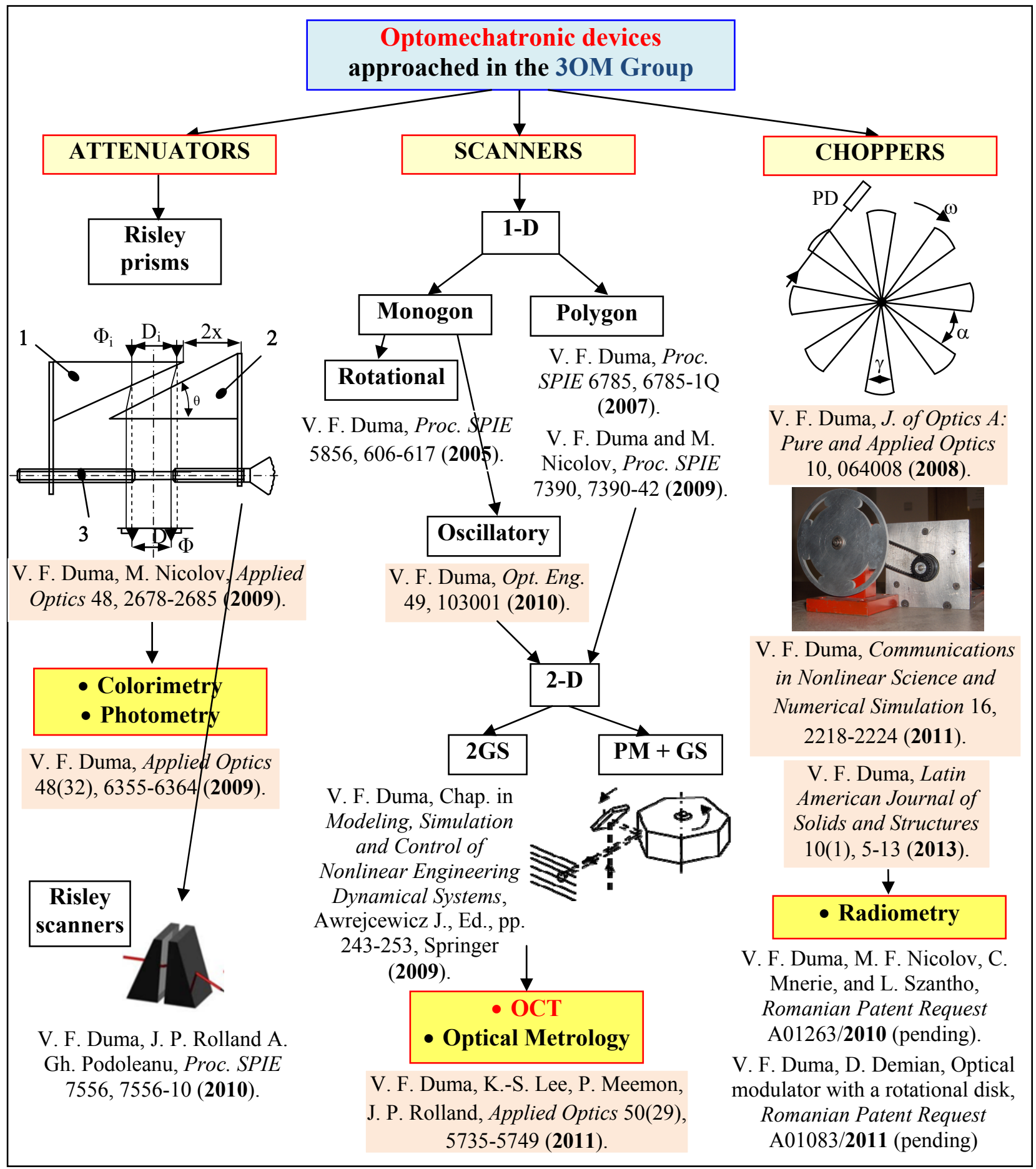

Figure 1. Research directions on devices in the 3OM Optomechatronics Group (with selected recent publications). 
Figure 1 presents an overview of the main directions of research in the 3OM Optomechatronics Group established in 2008 at the Aurel Vlaicu University of Arad. Our activity is divided in two broad directions, referring to optomechatronic devices and systems.

Thus, three main types of optomechatronic devices are pointed out in Fig. 1:

(1) Laser scanners [5, 6] and applications - subject of the Ph.D. thesis of the Group's head, defended 2001 [7]. Several types of scanners have been approached so far:

(a) Monogon scanners (plane rotational mirrors) [5, 6], for which the analysis has been made [7], as applied [8] in industrial dimensional measurements (on-line and real time) [9]. This direction of research is continued with aspects related to the dynamic balance of these fast rotating shafts.

(b) Polygonal mirror (PM) scanners have a fast scan rate due to their high rotational speed (up to 60 krpm nowadays), and they have the major advantage of providing a uni-directional scan. Their drawbacks are related to their multiple sources of errors [5], but their major issue is due to their inherent construction: the distance between the pivot and the facet produces a displacement of the point on which the reflection is produced on the PM facet - by contrast to the cases of the monogon rotational or of galvanometer (oscillatory) scanners, for which the laser beam can be focused on the rotational or oscillatory axis (which can be further more placed in the plane of the mirror). A designing calculus has been developed in the 90s on PMs [10], the issues of their lens and of the positioning of the PMs with regard to the optical axes of the lenses was studied [11], the scan patterns produced were investigated $[12,13]$, and their perspectives were highlighted [14, 15], despite the fact that they were replaced by galvoscanners in most applications in the $90 \mathrm{~s}$. We have developed an analysis of PM scanners [7], both analythical [9, 16] and numerical [17], in an optomechanical approach. Dynamic aspects of PMs are also under study in our group [18]. Other direction of research will be presented in Section 4.

(c) Galvanometer scanners (GSs) [19, 20] are the most used nowadays in all types of applications, especially for 2D (bi-dimensional) scanners used for lateral scanning in biomedical imaging, such as confocal microscopy and OCT (Optical Coherence Tomography). We have investigated them theoretically at first [21-23], and demonstrated [23] that the optimal scanning functions to be used is not linear plus sinusoidal, as pointed out previously in the literature [19], but linear plus parabolic - to produce the maximum possible duty cycle [23]. Experimental studies were also performed, for OCT applications, determining the optimal use of GSs in such systems [24]. These hot topics are followed by other studies, especially with PG students (Section 4).

(d) 2D scanners with dual axis GSs are the most used in OCT, by example. They are studied extensively to obtain the correction of the pincushion error [25], in order to achieve the topography of the probe after scanning in OCT [26, 27]. We have developed such an algorithm [28], while another promising avenue of research is in 2D scanners with PM plus GS (the former for the fast scan on one axis and the latter for precise positioning on the second axis).

(e) 2D scanners with Risley prisms have been studied extensively with regard to their scan patterns, inverse problem and applications [30-32], and we are studying them (with UG students for the time being) to determine their exact patterns [33], using wide-spread mechanical design programs such as CATIA.

(2) Optomechatronic choppers with rotational wheels are used in a wide variety of applications, from thermal imaging and pyrometry [34] to laser manufacturing (with top-hat laser beams) [35] and to biomedical imaging setups, by example for generating alternative images to obtain sequential OCT and confocal images [36]. Our researches on choppers followed the next steps:

(f) The theoretical analysis of "classical" macroscopic chopper with rotating wheels with windows with linear edges was developed [37], for top-hat laser beams (as utilized in manufacturing applications [35]) - and for all the possible relationships between the dimensions of the wheels and of the beam section in the plane of the wheel. One of the cases approached, of approximate trapezoidal impulses produced by the chopper has been previously investigated (but experimentally) by another group [38]. 
(g) A new device was introduced and developed, the "eclipse chopper", with wheels with windows with semi-circular edges, considered outward or inward [39]. We demonstrated that this is actually the general case of the classical choppers - which can be obtained from the eclipse choppers when the radiuses of the semi-circular margins go to infinity. The modulation functions obtained for the eclipse choppers [39] are therefore the general case of those obtained for the classical devices.

(h) Prototype wheels and modules were designed, constructed, and tested [40], based on the previous researches. This direction of research is now in full development in our group [41, 42].

(i) We are also developing a program for the design of choppers with rotating wheels (for different types of laser beams, such as top-hat, Gaussian and Bessel). The scope is to be able to obtain a certain profile of the laser impulses produced, and for this the parameters of the device have to be chosen properly [43];

(3) Optical attenuators with two ND (Neutral Density) translational Risley prisms were developed. They were studied in their three possible configurations, and the designing calculus of the variant demonstrated to be optimal (both from the optical and from the mechanical point of view) was completed [44]. Different types of attenuators are currently considered in our group as an alternative to these devices and to the use of choppers as optical attenuators [45].

Table 1. Research Grants coordinated by the 3OM Optomechatronics Group (activity in the last 5 years).

\begin{tabular}{|c|c|c|c|c|c|c|}
\hline Nr. & Funding Agency & Type of project & Title of the project & Members & Period & $\begin{array}{l}\text { Funding } \\
\text { Amount }\end{array}$ \\
\hline 1. & $\begin{array}{l}\text { Romanian } \\
\text { National } \\
\text { Authority for } \\
\text { Scientific } \\
\text { Research, } \\
\text { CNDI- } \\
\text { UEFISCDI }\end{array}$ & $\begin{array}{l}\text { IDEAS Grant, } \\
\text { code } 1896 / 2008\end{array}$ & $\begin{array}{l}\text { Analysis and design } \\
\text { of some polygonal } \\
\text { and galvanometer- } \\
\text { based, } 1 D \text { and } 2 D \\
\text { scanners }\end{array}$ & $\begin{array}{l}\text { Duma V. F. (PI) } \\
\text { Nicolov M. } \\
\text { PGs.: Mnerie C. } \\
\text { Szantho L. } \\
\text { Falcan O. }\end{array}$ & $\begin{array}{l}\text { Jan. } \\
2009- \\
\text { Dec. } \\
2011\end{array}$ & $\begin{array}{c}100 \mathrm{k} € \\
\text { (decreased } \\
\text { from } \\
370 \mathrm{k} € \text { due } \\
\text { to the } \\
\text { economic } \\
\text { crisis) }\end{array}$ \\
\hline 2. & $\begin{array}{c}\text { European } \\
\text { Commission } \\
\text { (EC) }\end{array}$ & $\begin{array}{l}\text { Erasmus } \\
\text { Program }\end{array}$ & $\begin{array}{c}\text { Exchange of } \\
\text { students and faculty } \\
\text { UAVArad - RWTH } \\
\text { Aachen, Germany }\end{array}$ & $\begin{array}{l}\text { Corves B. (Co-PI) } \\
\text { Duma V.F. (Co-PI) }\end{array}$ & $\begin{array}{l}2007- \\
2013\end{array}$ & $\begin{array}{l}\text { Variable } \\
\text { per year }\end{array}$ \\
\hline 3. & $\begin{array}{c}\text { US Department } \\
\text { of State } \\
\text { (at The Institute } \\
\text { of Optics, Univ. } \\
\text { of Rochester, } \\
\text { NY, USA) }\end{array}$ & $\begin{array}{c}\text { Fulbright Senior } \\
\text { Research Grant } \\
474 / 2009\end{array}$ & $\begin{array}{c}\text { Scanning in Swept } \\
\text { Source Optical } \\
\text { Coherence } \\
\text { Tomography (OCT) }\end{array}$ & $\begin{array}{l}\text { Duma V. F. (PI) } \\
\text { Host: Prof. J. Rolland }\end{array}$ & $\begin{array}{l}\text { Sept. } \\
\text { 2009- } \\
\text { June } \\
\mathbf{2 0 1 0}\end{array}$ & $\$ 26,450$ \\
\hline 4. & $\begin{array}{l}\text { Romanian } \\
\text { National } \\
\text { Authority for } \\
\text { Scientific } \\
\text { Research, } \\
\text { CNDI- } \\
\text { UEFISCDI }\end{array}$ & $\begin{array}{l}\text { PARTNERSHIP } \\
\text { Grant, } \\
\text { code PN-II-PT- } \\
\text { PCCA-2011-3.2- } \\
1682\end{array}$ & $\begin{array}{c}\text { Optical Coherence } \\
\text { Tomography (OCT) } \\
\text { systems with } \\
\text { handheld and } \\
\text { endoscope probes } \\
\text { for real-time } \\
\text { investigations in } \\
\text { material studies and } \\
\text { for in vivo medical } \\
\text { imaging; } \\
\text { http://3om-group- } \\
\text { optomechatronics.ro/ }\end{array}$ & $\begin{array}{l}\text { 30+ members from } 5 \\
\text { institutions (Table 2). } \\
\text { Members from the } \\
\text { 3OM Group: } \\
\text { Duma V. F. (PI) } \\
\text { Cira O. } \\
\text { Hutiu Gh. } \\
\text { Demian D. } \\
\text { Kaposta I. } \\
\text { PG: Mnerie C. } \\
\text { Several UGs }\end{array}$ & $\begin{array}{l}\text { July } \\
2012- \\
\text { July } \\
2015\end{array}$ & $950 \mathrm{k} €$ \\
\hline
\end{tabular}


As one of the essential aspects when establishing a research group in Engineering or Applied Physics is related to raising the necessary funding to develop a laboratory to carry on experimental works, in Table 1 we present the research grants carried on so far in the 5 years since the group was founded.

There are several other grants that we have participated to individually, but these are those on which the group was founded. The Laboratory of Optomechatronics, situated in the School of Engineering of the UAVA, was made on the first, IDEAS grant and is being completed on the following major one - of PARTNERSHIPS. To achieve this, most of the IDEAS Grant (about 60\%) was dedicated for equipments, and very few to salaries; some of the necessary mobility funding was completed by the Fulbright Grant that was carried on in the meanwhile.

A major issue that we had to face was the impact of the economic crisis that affected Eastern Europe and Romania in particular since 2009. This has led to a severe decrease of the funding for all research grants, and has also led to the decrease of our first grant (like of all similar Romanian grants) from 370 to $100 \mathrm{k} €$. Such financial issues still exist, although the situation improved significantly since then. This effort to raise funding continues in our group, to support PG students, especially, but also to complete the lab and to provide mobilities for training and participation at conferences - which is of course something that any group is doing.

The other directions of research of the 3OM Group, in optical systems this time will be presented in Section 4, in relationship with the work of the different PG and UG students in our group - but also in the various groups that we are collaborating with (Table 2). These directions have only been pointed out in Fig. 1, as following those on optomechatronic devices presented previously.

\section{THE 3OM OPTOMECHATRONICS GROUP. ENVIRONMENT AND COLLABORATIONS}

In Table 2 we present our main collaborative links that are active at present, both at national and at international level. To these institution there are often added, to our mutual benefit, the institutions (universities or companies) these collaborators work with as well - so the network is further enhanced - at least occasionally and on different specific topics.

We present in [46] this aspect, of our collaborative researches, and of our efforts to establish Photonics Pole in Western Romania, in the future metropolitan area Arad-Timisoara (planned to unite the two major cities in Western Romania, situated less than $50 \mathrm{~km}$ apart).

\section{TRAINING ACTIVITY WITH POSTGRADUATE STUDENTS}

The research directions of the 30M Group in optical systems, approached in the group, but mainly in the different collaborations pointed out in Table 2, are:

(1) Optical metrology - for on-line industrial dimensional measurements - Fig. 2 [7, 9, 47], have on-going PGs, but also UGs projects. Two such examples are provided in Fig. 3.

(2) Galvoscanners, for which our investigations have been presented in Section 2.1c, have mostly PG (both also occasionally UG) students working on different topics that include scanning and command functions of 1D GSs $[48,49]$, study and optimization of different control architectures of 1D GSs - Fig. $4[50,51]$ and driving algorithms of $2 \mathrm{D}$ dual galvos.

(3) OCT systems and investigations [52] and several related subassemblies - including swept laser sources scanned in frequency with PM scanners [53, 54] and 2D scanners with GSs [28] or with other 2D devices [33]) for lateral scanning in OCT. The research on which we obtained the rules-of-thumb for the optimal input functions of 1D GSs in OCT setups continues. We have so far demonstrated, in collaboration with the ODALab, UoRochester, NY [24] that the most artifact-free OCT images are obtained with triangular scanning, but further investigations are necessary to apply these aspects in OCT, as demonstrated by other groups that applied these aspects [55]. 
Table 2. Collaborative institutions with the 3OM Optomechatronics Group

\begin{tabular}{|c|c|c|c|c|c|}
\hline Nr. & $\begin{array}{l}\text { Type of } \\
\text { institution }\end{array}$ & Institution & $\begin{array}{l}\text { Group or School, } \\
\text { Director }\end{array}$ & $\begin{array}{l}\text { Domains of } \\
\text { collaboration }\end{array}$ & Remarks \\
\hline 1. & \multirow{6}{*}{$\begin{array}{l}\text { National / } \\
\text { Romanian }\end{array}$} & $\begin{array}{c}\text { Victor Babes } \\
\text { University of } \\
\text { Medicine and } \\
\text { Pharmacy Timisoara }\end{array}$ & $\begin{array}{l}\text { Imaging Group, School } \\
\text { of Dentistry }\end{array}$ & $\begin{array}{l}\text { Biomedical } \\
\text { imaging - OCT; } \\
\text { Materials for } \\
\text { dentistry }\end{array}$ & \multirow{4}{*}{$\begin{array}{l}\text { These collaborations } \\
\text { started in 2010-2011 and } \\
\text { are continuing on our } \\
\text { current Partnership Grant, } \\
\text { http://3om-group- } \\
\text { optomechatronics.ro/ } \\
\text { (with } 5 \text { institutions } \\
\text { involved, and coordinated } \\
\text { by the 3OM Group, with } \\
\text { Prof. Duma as PI) - as } \\
\text { described in detail in [46] } \\
\text { and as pointed out in } \\
\text { Table 1. }\end{array}$} \\
\hline 2. & & $\begin{array}{l}\text { SC Inteliform SRL } \\
\text { Timisoara }\end{array}$ & $\begin{array}{c}\text { Dynamic company } \\
\text { focused on mechatronics } \\
\text { and mechanics }\end{array}$ & $\begin{array}{l}\text { Developments } \\
\text { in micro- } \\
\text { mechanics }\end{array}$ & \\
\hline 3. & & $\begin{array}{c}\text { Arad County } \\
\text { University Clinical } \\
\text { Hospital }\end{array}$ & $\begin{array}{c}\text { Depts. of } \\
\text { GastroEnterology and } \\
\text { Hystopathology }\end{array}$ & $\begin{array}{l}\text { Endoscopy; } \\
\text { Hystopathology }\end{array}$ & \\
\hline 4. & & SC Bioclinica SA & $\begin{array}{c}\text { Largest array of } \\
\text { biomedical analyses } \\
\text { laboratories in Western } \\
\text { Romania }\end{array}$ & $\begin{array}{l}\text { Biomedical } \\
\text { analyses; } \\
\text { Hystopathology }\end{array}$ & \\
\hline 5. & & $\begin{array}{l}\text { Polytechnics } \\
\text { University of } \\
\text { Timisoara }\end{array}$ & $\begin{array}{l}\text { School of Mechanical } \\
\text { Engineering }\end{array}$ & $\begin{array}{l}\text { Including } \\
\text { Electron } \\
\text { microscopy } \\
\text { (SEM, TEM) }\end{array}$ & $\begin{array}{l}\text { Collaboration on several } \\
\text { projects (Table 1); current } \\
\text { work in various materials } \\
\text { studies using OCT. }\end{array}$ \\
\hline 6. & & $\begin{array}{l}\text { Polytechnics } \\
\text { University of } \\
\text { Bucharest }\end{array}$ & Robotics Group & $\begin{array}{l}\text { Mechatronics; } \\
\text { Robotics; }\end{array}$ & $\begin{array}{l}\text { Collaboration in the } \\
\text { establishment of the } \\
\text { EUROP_RO, Romanian } \\
\text { branch of the EUropean } \\
\text { RObotics Technology } \\
\text { Platform (EUROP), as } \\
\text { well as in the elaboration } \\
\text { of the national curiculla in } \\
\text { mechatronics and robotics }\end{array}$ \\
\hline 7. & \multirow{4}{*}{$\begin{array}{l}\text { Inter- } \\
\text { national }\end{array}$} & $\begin{array}{l}\text { University of Kent } \\
\text { at Canterbury, UK }\end{array}$ & $\begin{array}{l}\text { Applied Optics Group } \\
\text { (AOG), School of } \\
\text { Physical Sciences, } \\
\text { Director of the AOG - } \\
\text { Prof. A. Gh. Podoleanu }\end{array}$ & $\begin{array}{l}\text { Optics, } \\
\text { optomechanics } \\
\& \text { Photonics; } \\
\text { OCT }\end{array}$ & $\begin{array}{l}\text { Collaborations started in } \\
2008 \text {, especially on OCT, } \\
\text { with two members of the } \\
3 \text { OM Group as Visitings } \\
\text { of the AOG. }\end{array}$ \\
\hline 8. & & $\begin{array}{c}\text { University of } \\
\text { Rochester (UoR), } \\
\text { NY, USA }\end{array}$ & $\begin{array}{c}\text { ODALab, } \\
\text { Institute of Optics, } \\
\text { Director of ODALab - } \\
\text { Prof. J. Rolland }\end{array}$ & $\begin{array}{l}\text { Optical } \\
\text { Engineering } \\
\text { and Design; } \\
\text { OCT }\end{array}$ & $\begin{array}{l}\text { Collaborations started in } \\
2009 \text {, as Prof. Duma was } \\
\text { Fulbright Senior Research } \\
\text { Fellow at UoR - Table } 1 .\end{array}$ \\
\hline 9. & & $\begin{array}{c}\text { City University of } \\
\text { New York (CUNY), } \\
\text { NY, USA }\end{array}$ & $\begin{array}{c}\text { Nanofabrication Facility, } \\
\text { Director - Dr. I. } \\
\text { Voiculescu }\end{array}$ & $\begin{array}{l}\text { MEMS design, } \\
\text { fabrication and } \\
\text { testing }\end{array}$ & $\begin{array}{l}\text { Collaboration with Dr. } \\
\text { Voiculescu since the } 90 \mathrm{~s} \\
\text { - in precision mechanics. }\end{array}$ \\
\hline 10. & & $\begin{array}{l}\text { RWTH Aachen, } \\
\text { Germany }\end{array}$ & $\begin{array}{c}\text { Dept. of Mechanism } \\
\text { Theory and Dynamics of } \\
\text { Machines (IGM) }\end{array}$ & $\begin{array}{l}\text { Mechanical } \\
\text { Engineering }\end{array}$ & $\begin{array}{l}\text { Erasmus Program running } \\
\text { in Mechanisms and } \\
\text { Mechanical Engineering. }\end{array}$ \\
\hline
\end{tabular}


OCT applications, on which we are currently working on, are focused on dentistry (materials for dental works and prosthesis, investigations of soft and hard tissues) [56] - in collaboration with the School of Dentistry, Victor Babes University of Medicine and Pharmacy Timisoara - and on endoscopy and colonoscopy - in collaboration with the Departments of GastroEnterology and Hystopathology, Arad County University Clinical Hospital. Of interest are also material studies and art applications using OCT [57], but also other aspects of OCT [58] - all of these in collaboration with the AOG, UoKent, UK.

(4) Radiometric studies of optical systems, by example for vignetting [59], as well as photometry and colorimetry;

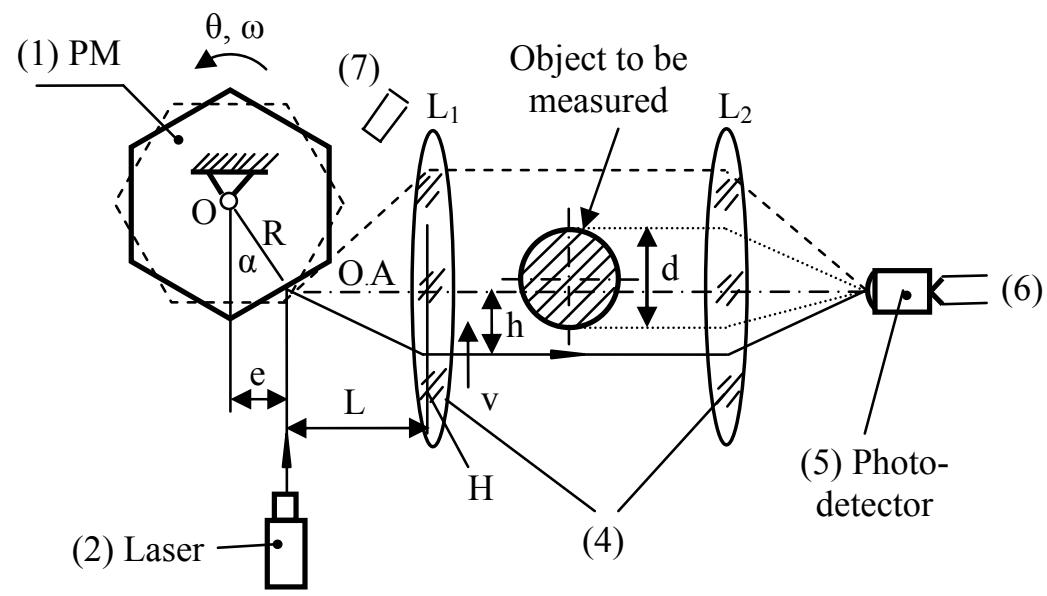

Figure 2. Optical micrometer with a Polygon Mirror (PM) scanner. The components are: (1) PM scanner; (2) laser; (3) power source for all the modules; (4) telescope lenses (the object to be measured is placed in-between); (5) photodetector for the measuring process; (6) signal retrieving unit (transmission link to the oscilloscope); (7) second photodetector, with trigger (to measure the scan frequency).

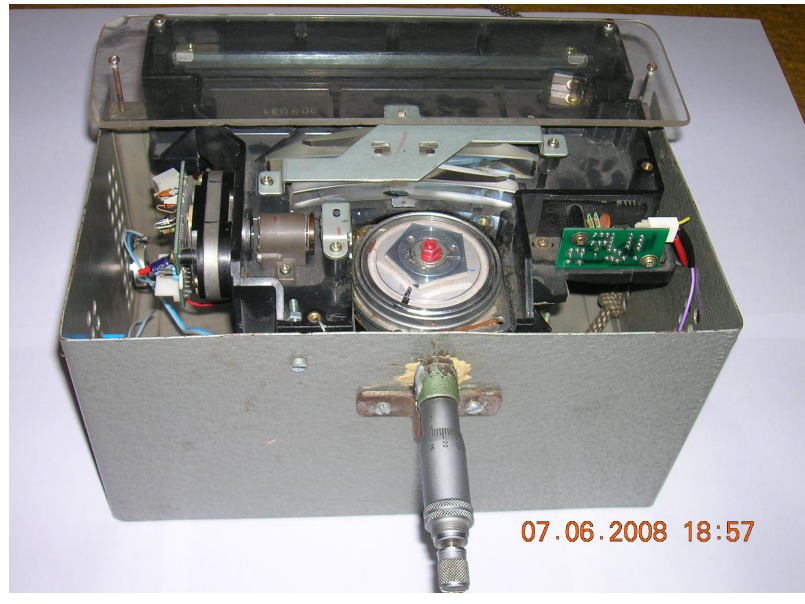

(a)

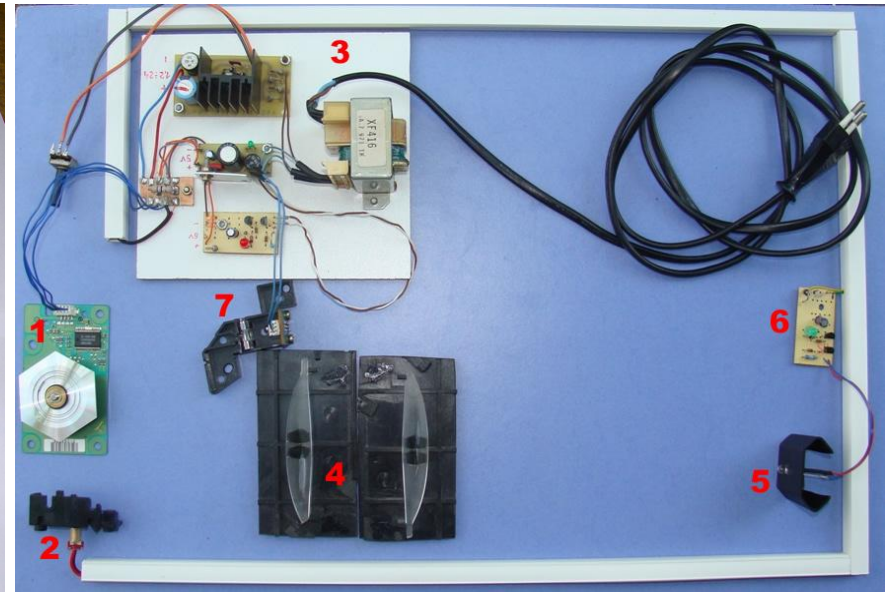

(b)

Figure 3. Examples of students' projects in optical metrology: (a) for verifying the scanning function of the polygons (with the adjustments of the parameters $e, L$, and $\omega$ of the assembly); (b) optical micrometer setup (with the same noitations as in Fig. 2). 
(a)
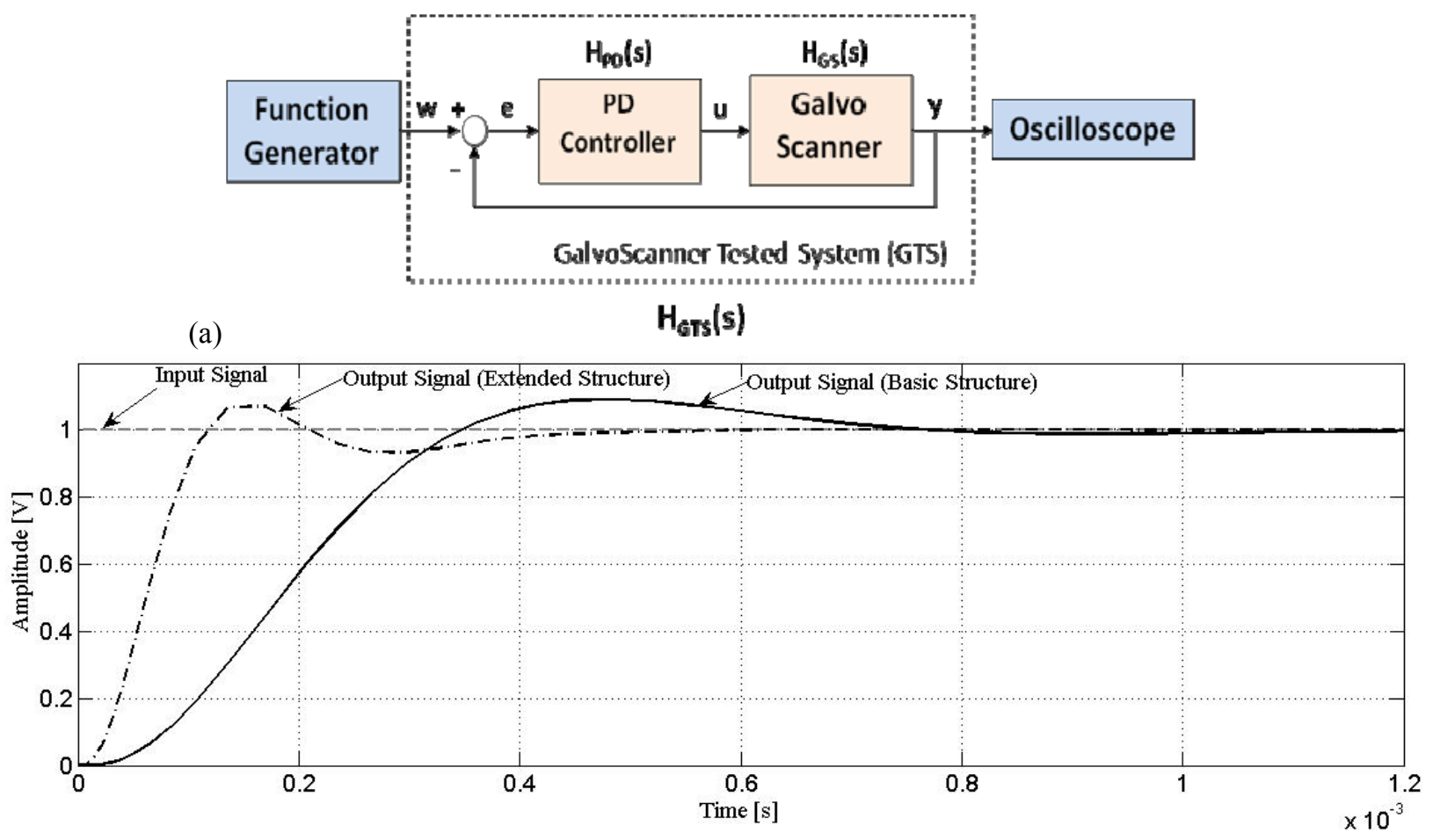

Figure 4. Study of the architecture of galvanometer scanners: (a) basic structure; (b) step function - response of the basic model versus the extended PID-L1 control structure [50, 51].

\section{TRANSLATION OF THE RESEARCH RESULTS IN THE UNDERGRADUATE STUDENTS' CURRICULA}

A detailed study of our strategy of moving from classical teaching to hands-on-experiments and to research-oriented teaching - even for undergrads - has been presented in detail in [60].

A brief presentation of our translation of the experience gained through research in the curricula of UG students has also been made in [61], while some aspects related to the training of PGs in the various groups involved in our current Partnership Project was described in [62].

An overview of the way the implementation of different research topics in the curricula of UG is made in Table 3 . While a major issue is the fact that an Optics program could not so far have started in our university, we are trying to do the best with Mechanical Engineering students, and especially with Electrical Engineering students, as the latter have a multitude of topics that include optoelectronics and photonics aspects.

\section{CONCLUSIONS}

The paper completes a brief presentation of the steps we have taken iin order to establish an Optomechatronics Group in a young university - with only 20 years of tradition - in the most Westen city of Romania, herself the most Eastern country of the European Union.

We have only pointed out a few of the issues we had, and insisted on the necessary steps we had to make in order to reach a level at which the group can start ot make steps towards becoming a partner for the international community. We briefly presented our main directions of research - both in devices and systems, the latter with a stress on industrial applications and on bimedical imaging. Training of PG and modern methods of teaching of UGs (with an accent on discovery through research) were also highlighted, as one of our main concerns.

Another aspect that is in our attention is related to collaborative links, inter- and multi-disciplinary, as well as to the possibility to transfer of the results of research into industry (and thus to the society). The collaborative link with two 
SMEs, one industrial and the other one specialized in biomedical analyses (Table 2), has been so far our approach in achieving this.

Future work implies both the enhancement of our research (with the effort to achieving results of interest, but also to publish in high impact journals) and of our collaborations to follow the path towards establishing the planned Photonics Pole in Western Romania [46].

Table 3. Implementation of several research topics in the curricula of the Mechanical \& Electrical Engineering undergraduate students at UAVArad.

\begin{tabular}{|c|c|c|c|}
\hline Domain & $\begin{array}{l}\text { Profile and } \\
\text { year of study }\end{array}$ & Topic & Lecture and labs \\
\hline Optics & $\begin{array}{l}\text { Electrical } \\
\text { Engineering, } \\
4^{\text {th }} \text { year }\end{array}$ & Instrumentation & $\begin{array}{l}\text { - Laser sources; } \\
\text { - Virtual Instrumentation - LabView (National Instruments } \\
\text { platform); } \\
\text { - Optomechatronic scanners; } \\
\text { - Optomechatronic choppers with rotating wheels; } \\
\text { - Handheld scanning probes for OCT; } \\
\text { - MEMS (Micro-Electro-Mechanical Systems); } \\
\text { - Endoscope scanning probes; } \\
\text { - OCT systems: TD (Time Domain), FD (Fourier Domain), SD } \\
\text { (Spectral Domain) and SS (Swept Sources); }\end{array}$ \\
\hline IT & $\begin{array}{l}\text { Electrical } \\
\text { Engineering, } \\
1^{\text {st }} \text { year }\end{array}$ & $\begin{array}{l}\text { Numerical } \\
\text { Methods }\end{array}$ & $\begin{array}{l}\text { - Transfer functions: Graphic representations; } \\
\text { - Optical choppers: Simulations and animations; } \\
\text { - Calculus of the areas between two curves - applications for } \\
\text { optomechanical devices. }\end{array}$ \\
\hline \multirow{4}{*}{ Electronics } & \multirow{3}{*}{$\begin{array}{l}\text { Electrical } \\
\text { Engineering, } \\
3^{\text {rd }} \text { year }\end{array}$} & $\begin{array}{l}\text { Computer } \\
\text { Peripherals }\end{array}$ & $\begin{array}{l}\text { - Polygon scanning heads for printers; } \\
\text { - Lens of photographic apparatuses, cameras, and webcams; }\end{array}$ \\
\hline & & $\begin{array}{l}\text { Modeling, } \\
\text { Identification } \\
\text { and Simulation }\end{array}$ & $\begin{array}{l}\text { - GS models - analytical and experimental identification; } \\
\text { - Galvoscanners: Mathematical modeling and Matlab / } \\
\text { Simulink simulations; } \\
\text { - Polygon scanners: Multi-parametric analysis; } \\
\text { - Modeling of actuators; }\end{array}$ \\
\hline & & $\begin{array}{c}\text { Automatic } \\
\text { Control Systems }\end{array}$ & $\begin{array}{l}\text { - Control architecture for 1D GSs - Design, simulation and } \\
\text { applications of the control structures; }\end{array}$ \\
\hline & $\begin{array}{l}\text { Electrical } \\
\text { Engineering, } \\
4^{\text {th }} \text { year }\end{array}$ & $\begin{array}{c}\text { Biomedical } \\
\text { Engineering }\end{array}$ & $\begin{array}{l}\text { - Biomedical imaging - techniques and systems; } \\
\text { - OCT, confocal and multiphoton microscopy; }\end{array}$ \\
\hline \multirow{4}{*}{ Mechanics } & $\begin{array}{l}\text { Mechanical } \\
\text { Engineering, } \\
1^{\text {st }} \text { year }\end{array}$ & $\begin{array}{l}\text { Materials } \\
\text { Studies }\end{array}$ & $\begin{array}{l}\text { - Non-distructive evaluations (NDE) of composite and non- } \\
\text { metallic materials using OCT; } \\
\text { - OCT investigations of polymers (for prosthesis, by example) }\end{array}$ \\
\hline & $\begin{array}{l}\text { Mechanical } \\
\text { Engineering, } \\
2^{\text {nd }} \text { year }\end{array}$ & Mechanisms & $\begin{array}{l}\text { - Polygonal mirror scanners - kinematics; } \\
\text { - Analogy between gears and Risley prisms scanners; } \\
\text { - Optomechanical scanners - dynamic aspects of fast rotational } \\
\text { shafts (bearings, windage, dynamic balance); }\end{array}$ \\
\hline & \multirow{2}{*}{$\begin{array}{l}\text { Mechanical } \\
\text { Engineering, } \\
3^{\text {rd }} \text { year }\end{array}$} & $\begin{array}{l}\text { Mechanical } \\
\text { Systems }\end{array}$ & $\begin{array}{l}\text { - Industrial measuring systems (optical micrometers), on-line } \\
\text { non-contact, with optomechanical scanners; }\end{array}$ \\
\hline & & $\begin{array}{l}\text { CAD-CAM } \\
\text { (Mechanical } \\
\text { Design) }\end{array}$ & $\begin{array}{l}\text { - Finite Element Analysis (FEA) of rotational polygons; } \\
\text { - Handheld scanning probes for OCT with 1D and 2D GSs; } \\
\text { - Optomechatronic choppers - mechanical design; }\end{array}$ \\
\hline
\end{tabular}




\section{ACKNOWLEDGMENTS}

This work was supported by a grant of the Romanian National Authority for Scientific Research, CNDI-UEFISCDI project number PN-II-PT-PCCA-2011-3.2-1682.

\section{REFERENCES}

[1] Karnopp, D. C., Margolis, D. L., and Rosenberg, R. C., [System Dynamics: Modeling and Simulation of Mechatronic Systems], 4th Edition, Wiley (2006).

[2] Cho, H., [Understanding Opto-Mechatronic Technology and its Applications], CRC / Taylor \& Francis (2003).

[3] www.3omgroup.appspot.com/

[4] http://www.idei-cdi.ro/monitor/index.php?page=detalii proiect

[5] Bass, M., [Handbook of optics], Mc. Graw-Hill Inc., New York, 30.1-30.26 (1995).

[6] Marshall, G. F., [Handbook of Optical and Laser Scanning], CRC Press, New York (2011).

[7] Duma, V. F., [Contribution to the analyses and the design of scanning systems], Ph.D. Theses, Polytechnics University of Timisoara, Romania (2001).

[8] Richter, B., "Laser scan devices for industrial application,“'WIRE 42(6), 529-540 (1992).

[9] Duma, V. F., "On-line measurements with optical scanners: metrological aspects," Proc. SPIE 5856, 606-617 (2005).

[10] Beiser, L., "Design equations for a polygon laser scanner," Proc. SPIE 1454, 60-66 (1991).

[11] Walters, C. T., "Flat-field postobjective polygon scanner," Appl. Opt. 34, 2220-2225 (1995).

[12] Li, Y. and Katz, J., "Asymmetric distribution of the scanned field of a rotating reflective polygon," Appl. Opt. 36, 342-352 (1997).

[13] Li, Y., "Single-mirror beam steering system: analysis and synthesis of high-order conic-section scan patterns," Appl. Opt. 47, 386-398 (2008).

[14] Sweeney, M. N., "Polygon scanners revisited," Proc. SPIE 3131, 65-76 (1997).

[15] Duma, V.F. and Podoleanu, A. Gh., "Polygon mirror scanners in biomedical imaging: a review," Proc. SPIE 8621, $8621 \mathrm{~V}(2013)$.

[16] Duma, V. F., "Novel approaches in the designing of polygon scanners," Proc. SPIE 6785, 6785-1Q (2007).

[17] Duma, V. F. and Nicolov, M., "Numerical and experimental study of the characteristic functions of polygon scanners," Proc. SPIE 7390, 7390-42 (2009).

[18] Duma, V.F. and Rolland, J. P., "Mechanical Constraints and Design Considerations for Polygon Scanners," Mechanisms and Machine Science, Vol. 5, Part 8, Pisla D., Ceccarelli M., Husty M., Corves B., Eds., 475-483, Springer (2010).

[19] Montagu, J., "Scanners - galvanometric and resonant," Chap. in Encyclopedia of Optical Engineering, R. G. Driggers, Ed., pp. 2465-2487, Taylor \& Francis, New York (2003).

[20] Gadhok, J. S., "Achieving high-duty cycle sawtooth scanning with galvanometric scanners," Proc. SPIE 3787, 173180 (1999).

[21] Duma, V. F. and Podoleanu, A. Gh., "Theoretical approach on a galvanometer scanner with an enhanced duty cycle," Proc. SPIE 7139, 71390D (2008).

[22] Duma, V. F., Podoleanu, A. Gh., Nicolov, M., "Modeling a galvoscanner with an optimized scanning function," SYROM 2009: Proc. of the $10^{\text {th }}$ IFToMM Intl. Symposium on Science of Mechanisms and Machines, 539-548 (2010).

[23] Duma, V. F., "Optimal scanning function of a galvanometer scanner for an increased duty cycle," Opt. Engineering 49(10), 103001 (2010).

[24] Duma V. F., Lee K.-S., Meemon P., and Rolland J. P., "Experimental investigations of the scanning functions of galvanometer-based scanners with applications in OCT," Appl. Opt. 50(29), 5735-5749 (2011).

[25] Li, Y., "Beam deflection and scanning by two-mirror and two-axis systems of different architectures: a unified approach," Appl. Opt. 47, 5976-5985 (2008).

[26] Ortiz, S., Siedlecki, D., Grulkowski, I., Remon, L., Pascual, D., Wojtkowski, M., and Marcos, S., "Optical distortion correction in Optical Coherence Tomography for quantitative ocular anterior segment by threedimensional imaging," Opt. Express 18, 2782-2796 (2010).

[27] Xie, J., Huang, S., Duan, Z., Shi, Y., and Wen, S., "Correction of the image distortion for laser galvanometric scanning systems,” Appl. Opt. 47, 5976-5985 (2008). 
[28] Duma, V. F., "Mathematical Functions of a 2-D Scanner with Oscillating Elements," Modeling, Simulation and Control of Nonlinear Engineering Dynamical Systems, 243-253 (2009).

[29] Kim, K. H., Buehler, C. and So, P. T. C., "High-speed, two-photon scanning microscope," Appl. Opt. 38, 60046009 (1999).

[30] Yang, Y., "Analytic solution of free space optical beam steering using Risley prisms," J. Lightwave Technol. 26, 3576-3583 (2008).

[31] Warger II, W. C. and DiMarzio, Ch. A., "Dual-wedge scanning confocal reflectance microscope," Opt. Letters 32, 2140-2142 (2007).

[32] Garcia-Torales, G. Strojnik, M. and Paez, G., "Risley prisms to control wave-front tilt and displacement in a vectorial shearing interferometer," Appl. Opt. 41, 1380-1384 (2002).

[33] Schitea A., Tuef M., and Duma, V. F., "Modeling of Risley prisms devices for exact scan patterns," Proc. SPIE 8789, 8789-40 (2013).

[34] Leonov, V. N. and Butler, D. P., "Two-color Thermal Detector with Thermal Chopping for Infrared Focal-Plane Arrays," Appl. Opt. 40, 2601-2610 (2001).

[35] Wan, D.-P., Liu, H.-B., Wang, Y.-M., Hu, D.-J., Gui, Z.-X., " $\mathrm{CO}_{2}$ laser beam modulating for surface texturing machining," Optics \& Laser Technology 40, 309-314 (2008).

[36] Podoleanu, A. Gh., Dobre, G. M., and Cucu, R. G., "Sequential optical coherence tomography and confocal imaging," Opt. Letters 29, 364-366 (2004).

[37] Duma, V. F., "Theoretical approach on optical choppers for top-hat light beam distributions," J. of Optics A: Pure and Applied Optics 10, 064008 (2008).

[38] Benjamin, K., Armitage, A., and South, R., "Harmonic errors associated with the use of choppers in optical experiments," Measurement 39, 764-770 (2006).

[39] Duma, V. F., "Optical choppers with circular-shaped windows: Modulation functions," Communications in Nonlinear Science and Numerical Simulation 16(5), 2218-2224 (2011).

[40] Duma, V. F., "Prototypes and modulation functions of classical and novel configurations of optical chopper wheels," Latin American Journal of Solids and Structures 10(1), 5-18 (2013).

[41] Duma, V. F., Nicolov, M., Kiss, M., Ilca, T., Demian, D., and Szantho, L., "Modeling of modulation functions of different configurations of optical chopper wheels," Proc. SPIE 8083, 8083-17 (2011).

[42] Duma, V. F., "Classical and eclipse optical choppers," Proc. SPIE 8621, 8621-44 (2013).

[43] Cira, O. and Duma, V. F., "Transmission functions of optical choppers for Gaussian beam distributions: Modeling and simulations," Proc. SPIE 8789, 87890E (2013).

[44] Duma, V. F. and Nicolov, M., "Neutral density filters with Risley prisms: analysis and design," Appl. Opt. 48, 2678-2685 (2009).

[45] Duma, V.F., Nicolov M., and Kiss M., "Optical choppers: modulators and attenuators," Proc. SPIE 7469, 74690V (2010).

[46] Duma, V. F., Negrutiu, M. L., Sinescu, C., Miutescu, E., Burlea, A., Vlascici, M., Negru, C., Gheorghiu, N., Demian, D., Hutiu, G., Mnerie, C., Marcauteanu, C., Topala, F., Voiculescu, I., and Podoleanu, A. Gh., "Towards a Research Pole in Photonics in Western Romania," Proc. SPIE ET100, ET100-106 (2013).

[47] Duma, V. F., "Dimensional measurements with optical scanners," Proc. $4^{\text {th }}$ European Workshop on Structural Health Monitoring (ESHM), 1217-1224 (2008).

[48] Duma, V. F., "Command functions of open loop galvanometer scanners with optimized duty cycles," Theoretical and Applied Mechanics Letters 2(4), 043005 (2012).

[49] Duma, V.F. and Mnerie, C., "Optimization of scanning and command functions of galvanometer-based scanners," Proc. SPIE 8083, 8083-45 (2011).

[50] Mnerie, C., Preitl, S., and Duma, V. F., "Mathematical model of a galvanometer-based scanner: simulations and experiments," Proc. SPIE 8789, 8789-43 (2013).

[51] Mnerie, C., Preitl, S., and Duma, V. F., "Performance Enhancement of Galvanometer Scanners Using Extended Control Structures," SACI: 8th IEEE International Symposium on Applied Computational Intelligence and Informatics, 127-130 (2013).

[52] Huang, D., Swanson, E. A., Lin, C. P., Schuman, J. S., Stinson, W. G., Chang, W., Hee, M. R., Flotte, T., Gregory, K., Puliafito, C. A. and Fujimoto, J. G., "Optical coherence tomography," Science 254(5035), 1178-1181 (1991).

[53] Yun, S. H., Boudoux, C., Tearney, G. J. and Bouma, B. E., "High-speed wavelength-swept semiconductor laser with a polygon-scanner-based wavelength filter," Opt. Letters 28, 1981-1983 (2003). 
[54] Oh, W. Y., Yun, S. H., Tearney, G. J. and Bouma, B. E., "115 kHz tuning repetition rate ultrahigh-speed wavelength-swept semiconductor laser," Opt. Letters 30, 3159-3161 (2005).

[55] Braaf B., Vermeer, K. A., Vienola, K. V., and de Boer, J. F., "Angiography of the retina and the choroid with phase-resolved OCT using interval-optimized backstitched B-scans," Opt. Express 20, 20516-20534 (2012).

[56] Sinescu, C., Negrutiu, M. L., Todea, C., Balabuc, C., Filip, L., Rominu, R., Bradu, A., Hughes, M., Podoleanu, A. Gh., "Quality assessment of dental treatments using en-face optical coherence tomography," J. of Biomedical Optics 13(05), 054065 (2008).

[57]Liang, H., Cid, M. G., Cucu, R. G., Dobre, G. M., Podoleanu, A. Gh., Pedro, J., Saunders., D., "En-face optical coherence tomography - a novel application of non-invasive imaging to art conservation," Opt. Express 13, 61336144 (2005).

[58] Duma, V. F., Rolland J. P., and Podoleanu, A. Gh., "Perspectives of optical scanning in OCT," Proc. SPIE 7556, 7556-10 (2010).

[59] Duma V. F., "Radiometric versus geometric, linear and non-linear vignetting coefficient," Appl. Opt. 48(32), 63556364 (2009).

[60] Duma, V. F., "Teaching Mechanisms: from Classical to Hands-on-Experiments and Research-Oriented," Mechanisms and Machine Science 5(8), 493-501 (2010).

[61] Duma, V. F., Schitea, A., Tuef, M., Cira, O., Hutiu, Gh., Demian, D., Mnerie, C., and Kaposta, I., "Optomechatronics applications of the theory of mechanisms with active student involvement in research," New Trends in Educational Activity in the Field of Mechanism and Machine Theory 19, 111-119 (2013).

[62] Duma, V. F., Negrutiu, M. L., Sinescu, C., Voiculescu, I., Miutescu, E., Burlea, A., Vlascici, M., and Podoleanu, A. Gh., "Research lead student projects on multi-disciplinary optomechatronics with applications in biomedical imaging," New Trends in Educational Activity in the Field of Mechanism and Machine Theory 19, 145-153 (2013). 